\title{
Implementation of Ulama Cadre Education at the Indonesian Ulama Council of Bogor Regency
}

\author{
Ta'rif ${ }^{1}$, Husen Hasan Basri ${ }^{2}$ \\ \{ta75rif@gmail.com ${ }^{1}, \underline{\text { hahabe1076@gmail.com² }}$ \} \\ Center for Research and Development of Religious Education, \\ Ministry of Religious Affairs of The Republic of Indonesia \\ J1, MH Thamrin No. 6 Jakarta $^{1,2}$
}

\begin{abstract}
The existence of ulama is currently a common concern from various groups, related to the lack of quality and quantity of scholars. Islamic boarding school education institutions and religious mass organizations that seek to overcome the scarcity of ulama through cadre education. However, these efforts have not shown maximum results. MUI Bogor Regency is one of the institutions that has carried out the education program for the regeneration of ulama from 2006 to the present. This paper is focused on how the implementation of education for ulama cadres, how is the continuity of the PKU implementation program at MUI, Bogor district. This study found that the success of the implementation of ulama cadre education at MUI in Bogor Regency is due to, first, solid leadership, second, the support of the youth generation / youth, and PKU alumni, and thirdly the synergy of ulama and umara, namely the support of PKU program funding from the local government, networks with religious institutions (Islamic organizations) and universities.
\end{abstract}

Keywords: Implementation, Ulama Cadre Education

\section{Introduction}

Currently, there are fewer people who get the recognition of the predicate of scholars who are understanding of the times (faqihu lizamanihi), both in terms of quality and quantity. The occurrence of this leadership crisis of the ummat / ulama: Internally: the number of ulama who are currently elderly and dead, have not been able to measure the ulama who have the quality / competence of the ulama, which are impressed by the depth of knowledge and moral competence, which have emerged, there is a shift the orientation of Islamic religious education institutions - pesantren - from deepening the religious knowledge of tafaqquh fid-din to meeting the needs of the community for general knowledge by opening public elementary schools, junior high schools, and high schools, as well as public schools with distinctive Islamic characteristics including the establishment of universities in the neighborhood boarding school.

Externally, the occurrence of social changes in society such as advances in science and technology and globalization has a superficial impact on the reproduction of scholars, tafaqquh fi al-din, Islamic values, traditionalism, establishment of the yellow book study using the sorogan, bandongan, and memorization methods. Globalization affects the lives of students, clerics, kiai and educational media. Santri who are affected by globalization seem more critical, but religious discipline has relatively decreased. Kiai and Ustdaz who are affected by globalization have changed their life format which is identified in the increasing horizons of their thinking and their desire to consume global products [1]. 
In the past the process of regenerating ulama in pesantren was natural. Kyai initially did not intend to prepare students to become scholars. Kyai frees his students to become anything. A pesantren kiai only teaches religious sciences and guides his students to have a good Muslim personality as well as benefit the community. Although the leadership of the pesantren did not specifically prepare their students to become ulama, the pesantren were proven to have produced and produced reliable scholars. Both on a local and international scale, Islamic boarding schools have produced ulama figures who have scientific authority and integrity, besides that they have expertise in certain scientific fields.

There are various ways and efforts to deal with the crisis or the scarcity of ulama, whether done by Islamic boarding schools such as the noble Islamic boarding school program in the 1960s, Ma'had Aly from the 1990s to the present, Takhassus Diny or those carried out by the community such as the education of ulama cadres (PKU). ) conducted by MUI in the 1990s, the ulama cadre program carried out by a number of Islamic Diversity Organizations, such as Nahdlatul Ulama (Kader Ulama Fiqh), Muhammadiyah (Cadre Tarjih Ulama), ulama cadre activities carried out by the Indonesian Islamic Da'wah Council (DDII), and others. other.

In addition, the education of clerical cadres has also become an important concern for ulama circles, especially since MUI was first established. Through various meetings, the idea of the need for education for the regeneration of ulama continued to roll and was getting stronger, finally this problem was caught by several groups, both the ulama and the government. The government through the Ministry of Religion at the time of minister Munawir Sjadali prepared the idea of establishing Madrasah Aliyah Special Programs in various regions. This idea is a form of concern in preparing madrasa alumni who are tafaaqquh fiddin. This program continues to receive positive responses from various circles of society, so that several other regions have opened Madrasah Aliyah Special Programs (MAPK) education programs.

The Central MUI has also opened a scholarly cadre education program by cooperating with universities (IAIN Syarif Hidayatullah Jakarta). The PKU program has been implemented for two years, originating from all over Indonesia with strict selection from various provinces, participants get hostel facilities, reference books, pocket money, and others. But over time and the change of government. The Central MUI PKU program did not last long, as a result it stopped and did not run as it should. The big obstacle that was a factor in its stopping was cost.

Several studies related to the education of ulama regeneration include: Center for Research and Development of Religious Education 2003 conducted a study in order to evaluate Ma'had aly program. The results of the study concluded that pesantren were the most likely religious educational institutions for organizing ma'had aly because these institutions had sufficient intellectual, social and cultural potential [2].

Center for Research and Development of Religious Education (Puslitbang Penda) 2007 concerning Public Perceptions and Aspirations of the Preparation of Ulama Cadres in Pesantren, shows that the pesantren community (residents /non-pesantren) perceives pesantren as still functioning as an ulama preparation institution, therefore pesantren institutions are perceived by them to be capable of producing ulama cadres [3].

Research by Center for Research and Development of Religious Education (Puslitbang Penda) in 2008 on the Need Assessment for the development of the Ma'had Aly curriculum resulted that the birth of Ma'had 'Aly's education was a response from the pesantren world to the demands of a system outside it, therefore ma'had Ali as an education for prospective kyai / ulama or community leaders must anticipatory and compatible with existing changes. The concern is the increasing scarcity of qualified ulama (ulama lizamanihi) is related to the fading of the intellectual tradition and scientific building of Islamic boarding schools based on the yellow book [4]. 
Muhtarom HM in his dissertation on the Reproduction of Ulama in the Era of Globalization: Traditional Islamic Resistance, which took the case of two traditional Islamic boarding schools in Pati district, Central Java, namely the Raudlatul Ulum Islamic Boarding School and the Bustanuth Tholibin Islamic Boarding School, the results of his research show that globalization has no effect on the 'aqidah area. traditional Islamic boarding school community. Globalization has a superficial impact on the reproduction of ulama, tafaqquh fi al-din, Islamic values, traditionalism, establishment of the yellow book study using sorogan, bandongan, memorization, and contemplative habits... [5].

The Bogor Regency MUI Institute has collaborated with the Bogor Regency government since 2006 to organize an education program for ulama cadres (PKU). This activity has entered the eighth generation, where in this program it is not only given an in-depth study of Islamic sciences, but also other supporting sciences which are expected to become scholars who are ready to use in society. This program has received appreciation from various circles and has become a reference for several other regions in developing ulama cadre programs.

This paper is focused on issues concerning: first, how is the system of implementation practice (input, process and output) of education for ulama cadres at MUI Bogor Regency?, and second, how is the continuity of the PKU implementation program at MUI Bogor Regency?.

\section{The Concept of Ulama Cadre Education}

Preparation is a noun which means the process, method, act of preparing or facilitating something [6]. regeneration is a long-term educational process to optimize cadres' potentials by transferring and instilling certain values, so that later it will give birth to strong cadres.

Preparation of ulama means the process or method of preparing the ulama cadre carried out by the institute. In other words, the preparation of ulama is a process or way of educating students who are prepared to become ulama cadres. Various programs have been carried out both by the pesantren themselves, such as the noble pesantren program in the 1960s, ma'had aly since the 1990s until now, takhassus sung or those carried out by the community such as the ulama cadre education (PKU) carried out by MUI in 1990- an, the ulama cadre program carried out by the Muhamadiyah boarding school, the ulama regeneration activities carried out by the Indonesian Islamic Da'wah Council (DDII), and others.

Ulama in the perspective of the Koran and hadith are people who have knowledge of the verses of Allah both kawniyah (natural phenomena) and quranic and with their knowledge they are istislam (submissive) and khasyyah (fear) of Allah. Submitting and fearing Allah is a dividing line between scholars, scholars or anyone who is knowledgeable about natural phenomena or even the teachings of al-quran (religion) and scholars. There are four main tasks that scholars must carry out in accordance with their prophetic duties in developing the Scriptures: first, conveying (tabligh) teachings. Second, explain the teachings. Third, decide the problems facing society. Fourth, provide examples of practice [7].

The cleric is related to the term 'ilm which means knowledge (knowledge). 'Ilm is different from ma'rifah which also means knowledge. In the original sense, the first term refers to knowledge of the highest quality which can sometimes be obtained only intuitively, while the second term refers to knowledge in general. In classical usage, 'ilm does not have the plural form. However, in post-classical Arabic, a plural form was introduced, namely 'ulum, which refers to various' ilms of several kinds of knowledge. In the context of this latter meaning, not everyone who has' ilm (knowledge) can be called a scholar; only those who are experts in the religious sciences ('ulum al-diniyyah) have the privilege of being called scholars. Therefore, the complex growth of scholars is closely related to the development of the concept of 'ilm itself 
among the Muslims [8].

Ulama is referred to as the plural form of 'alim meaning one who is knowledgeable. Initially, ulama were scientists in both religion and nature. However, in its development, especially in the everyday sense, the meaning of ulama was narrowed down, so that ulama was only used for people who were engaged in religious disciplines. Especially in Indonesia, scholars also have different designations in each region, such as Kiai (Java), Ajengan (Sunda), Tengku (Aceh), Syeikh (Tapanuli, North Sumatra), Buya (Minangkabau), Tuan Guru (Nusa Tenggara, South Kalimantan, Kaltim), Anrongguru (Makasar), anregurutta (Bugis) [9].

Entering the 20th century - it can be said that until recently, ulama had various roles. In line with their social base, the involvement of ulama in the socio-political world seems to be very strong in coloring the lives of a number of ulama. Islamic boarding school clerics are not only involved in the world of pesantren education. Therefore, today pesantren not only have three important roles; as a center of transmission of traditional Islamic scholarship, a preserver of traditional Islam, and a center for reproduction of ulama, but pesantren - to borrow Azra's term is an alternative to people-centered development and at the same time as a center for valueoriented development. oriented development) [10].

Ulama regeneration is an educational process carried out by certain institutions / institutions to produce ulama cadres. Ulama are people who know the religious sciences and with their knowledge submit and fear Allah. Ulama Cadre education is an education system consisting of input, process and output. Ulama cadre education here concerns educational orientation, vision and mission of education, material and curriculum, learning process, evaluation, achievement, and graduation.

\section{Research Methodology}

The research was conducted at the Indonesian Ulema Council (MUI) Bogor Regency. Data collection was carried out in 2014. The study used qualitative methods with the types of cases. The data sources of this research are Bogor Regency MUI Management, PKU MUI Management, PKU Alumni, PKU Lecturers, Members of the Regency DPRD. Bogor, Bintal Office of Bogor Regency Government, Community. In addition to the researcher as an instrument, the data collection instrument was an observation guide, interview guide, documentation study. Data collection techniques are carried out through observation, interviews, and documentation. While the data analysis technique was carried out by "qualitative descriptive analysis and qualitative verification". For this reason, the researcher categorizes and classifies the data that has been obtained from the field. Meanwhile, to test the validity of the data, the researcher verified and compared data from various sources, both oral and action sources through interviews, writing (documents) and data obtained through observation. Information or data about the research problem that has been obtained, is then studied carefully, analyzed, discussed and examined in depth, after which editing, description and verification are carried out.

\section{History of Ulama Cadre Education at MUI Bogor Regency}


In the era of the 1970s before the birth of the Joint Decree (SKB) of three ministers, education running in Islamic boarding schools and madrasas were educational institutions based on the cadre of ulama, because the curriculum he was studying was the science of Islam and the books he studied. Arabic (yellow book). However, after the birth of the SKB, the function of this educational institution gradually shifted gradually to a general education institution that was 'polished' with religious values.

This shift in function then automatically has an important impact, namely the distant vision of ulama cadre in the midst of community education. Especially if we refer to the current developments, the swift flow of ICT-based education (Information Communication and Technology) has a special challenge in advancing the ulama cadre system in this country. It could be that there are more and more religious scholars, the quantity of preachers and da'i is also increasing. However, not many are included in the criteria of scholars. The people began to feel the scarcity of scholars. The Ministry of Religion, Higher Education of Islamic Religion (PTAI), and MUI in various parts of the archipelago are starting to feel anxious about the scarcity of the next generation of scholars. Because being a scholar is not only knowledgeable, but also he must master it and have good morals (wara ') and be able to be a role model or role model for the people.

From the results of the study, it was stated that the institutions that produced many ulama came from the womb of Islamic boarding schools, as Azyumardi Azra stated that pesantren had three traditional functions, namely: first, transmission and transfer of Islamic knowledge; second, maintaining the Islamic tradition; and third, the reproduction of the ulama [11]. With this distinctive function and position, Islamic boarding schools are expected to be able to play their traditional functions, especially for the reproduction of ulama. However, given the condition of the material, methods and strategies of learning in Islamic boarding schools at this time it can be assumed that it is difficult to "produce a cadre of ulama" as has been done by a number of Islamic boarding schools in the past. This shows that at this time there must be concrete efforts regarding the regeneration of ulama. This means that those with a contention in carrying out "ulama cadre education" must collaborate with various parties, including the government, Islamic boarding schools, community leaders, religious organizations and community organizations in carrying out the education of ulama cadre. If not, then it is possible that ulama will become rare items that are difficult to find in Indonesia.

Ulama as role models, a place to ask questions and a place to complain about various life problems, at this time are thought to have decreased both in terms of quality and quantity. This condition is one of the factors that can motivate the Indonesian Ulema Council, Kab. Bogor to program the Ulama Cadre Education (PKU) as an effort to educate and prepare quality scholars in the future. Therefore, PKU is an annual mandatory agenda for MUI Bogor, because PKU graduates are increasingly competitive, innovative and proven to be able to take part in national development in general and in the development of Bogor in particular. This, of course, is closely related to the vision and mission that leads to the management structure and work program of the Indonesian Ulema Council, Bogor.

Among the reasons behind the opening of the ulama cadre program in Bogor Regency are: first, nationally, there has been a decrease in qualified ulama while the problems of society are increasingly complex, because it needs a forum to prepare cadres of ulama who are ready to deal with these problems. Second, in Bogor Regency as a religious society in 2006 the emergence of several heretical sects that threaten the faith of the Muslim community, such as Ahamadiyah which has the Al-Mubarak campus owned by Ahmadiyah which is the center of its activities in Parung, which led to the invasion and prohibition of this understanding, the emergence of the understanding Mahesa brackets that lead to court up to the cassation level, the case of the False 
Prophet Muhammad Mosadeq, and others. Third, the clerical figures or elderly kyai who have started to age and die while graduate graduates from Islamic universities are still weak in terms of mastery of the yellow books [12]

Thanks to the support of all parties, especially the local government, since 2006 the PKU program was opened, and now it is the eighth generation. The Ulama Cadre education program at MUI Bogor has received appreciation from various groups, ranging from local, central, and tertiary institutions who deliberately come to have an audience at MUI or invite to the venue. Among the visits, such as the MUI of Kampar district, Brunei Darussalam University, were specially invited by the Hong Kong Muslim community and followed up by the Hong Kong Consulate General; Invitation from the University of Frankfurt Germany, In 2015 there were two PKU alumni who were given the opportunity to take part in the education program at Rabithah Alam Islami [13]

The PKU program is an alternative solution to address these challenges. The holding of this educational program is intended to build a paradigm that it is time for Muslims to always strive to prepare their next generation in a systemic way in a planned education according to the intended goals and objectives. The PKU program is an effort of the Bogor Regency MUI in responding to the interests and talents of Muslims and Muslim women who want to explore Islamic religious sciences in order to prepare themselves to become scholars who are urgently needed by the ummah today.

Sociologically, the term ulama in society is given to someone on the basis of understanding and mastery of the Islamic religious sciences as well as their behavior and piety which deserves to be emulated and emulated. In general, they are Islamic boarding schools who are able to read Arabic books, understand Islam comprehensively and become role models for their noble behavior. Therefore their position among the ummat is highly respected and respected.

Seeing the reality that has happened recently in society, the challenge of preaching is getting tougher to face. Not only because of the influence of modernism and globalization that touches down to the lower level, but also coupled with the lack of public interest in deepening Islam seriously. This poses a serious threat to the Muslim ummah as a whole, because if religion is no longer in demand, it will create dzurriyyatan dhi'afan (weak people) who are far from divine values.

PKU was born not only to create reading the yellow book, but also required to be able to write English and Arabic, which currently many scholars have the ability orally, write papers. Giving birth to scholars who are experts not only in oral but also through writing. Thus PKU is directed towards mastery of religious and general sciences and can work together with umara [14]

Thus, the learning process at PKU in addition to learning materials is theoretical, for example; In PKU, participants (students) are also required to take part in field activities in order to get a concrete picture of real conditions in the field. Among the series of field activities, is a road show with a seminar with the theme "Preventive Movement to Prevent Deviating Streams" in five districts. Bogor, filled a lecture on Radio Suara Ulama (Suma), internships at several Islamic education institutions and field research.

\section{Implementation of Ulama Cadre Education}

PKU is carried out once a year which lasts for 3 months with a burning system of 66 credits. The implementation of the Ulama Cadre will take place from Saturday at 09.00 to 22.00 WIB until Sunday at 12.00 WIB. While the place of learning at MUI Kab. Bogor, Cibinong and Yayasan Dharmais Cimandala Sukaraja Kab. Bogor. Program visits to various educational 
institutions, research institutes, publishing institutions and others, and research or research activities.

PKU is designed as a cadre system that combines various components that are interrelated with one another and function synergistically well to support the achievement of goals. The components in question are grouped into: first, row input, namely students who will go through the educational process in order to develop into graduates or outputs with qualifications defined in the objectives. Second, instrumental input (input instrument), namely input in the form of components that enable the educational process to occur. This component includes education personnel, management, curriculum and educational tools. Third, Environmental Input, which is input in the form of components that directly or indirectly affects the role of instrumental input in processing raw inputs. This component includes social, cultural, economic, political and security factors.

\section{1. PKU Participants / Students}

PKU participants are called students. They are recruited with the following qualifications: Graduates from Higher Education or Islamic Boarding Schools, Able to read yellow books, Evidenced by passing written and oral tests, Minimum age 21 years and maximum 35 years, Willing to participate in the program in full, and Willing to follow PKU rules and disciplines . Participants must take an Entrance Test which includes: 1) Written examination of Islamic sciences, Arabic and English, 2) Oral examination, including: Al-Quran test, Arabic test and motivation test., 3) Interview, 4) Submitting Papers on Islamic and social issues preferably in Arabic or English at least 5 pages. After being accepted as PKU participants, participants get rights and obligations, namely: getting free books: Participants are required to send email requests for books / books / al-Qur'an etc. to Islamic institutions that provide free books (the address of the institution will be notified when lecture).

Among the obligations of participants to participate in PKU are participants who are obliged to donate books for the MUI Kab. Bogor. The criteria for waqf books: new books are not used books, books discuss Islamic themes such as Islamic politics, Sufism, history, Arabic, Islamic thought and so on, The thickness of the waqf book is at least 200 pages, Waqf books are in Indonesian, Arabic or English, Participants PKU is also required to write a review or synopsis of the books available in the MUI yellow book library, Kab. Bogor. The provisions of the book that are reviewed and the format for the reviews will be notified later during the lecture.

Participants are required to do internships at Islamic institutions such as Islamic boarding schools, the Jami 'mosque's DKM, Islamic organizations, Amil Zakat, Infaq and Sadaqah bodies (BAZIS), Majelis Taklim Contact Agency (BKMT), etc. Apprentices are required to carry out a SWOT (Strength, Weakness, Opportunity, Threat) analysis of the institution where they are interning. Participants are also required to do field practice. Field practice can take the form of filling in recitation at the ta'lim assembly, general recitation, religious lectures and others. The committee prepares an assessment form which will be filled in by the leadership / management of the place concerned. Field practice submission reports must be received a maximum of 2 weeks before the course ends. For the Islamic Digital Library course, all participants will get a free Maktabah Syamilah tutorial module.

PKU has produced alumni who have been active in society. Starting from the first to the seventh generation and soon the eighth generation alumni. PKU alumni are strategic enough to produce young kyai, not a few alumni who become community leaders, educators, and continue the relay of MUI management at the sub-district and district levels [15]. 
PKU Alumni Graph

\begin{tabular}{ccc}
\hline Generation & Participants & Year \\
\hline 1 & 38 & 2007 \\
\hline 2 & 37 & 2008 \\
\hline 3 & 47 & 2009 \\
\hline 4 & 50 & 2010 \\
\hline 5 & 50 & 2011 \\
\hline 6 & 49 & 2012 \\
\hline 7 & 50 & 2013 \\
\hline 8 & 50 & 2014 \\
\hline Total & 371 & \\
\hline
\end{tabular}

\section{2. Instructor / Lecturer}

Lecturers for Ulama Cadre Education (PKU) at MUI Bogor Regency come from Ulama, academics and experts who have expertise and capacity in their fields, with the hope that students can add scientific, Islamic and Indonesian insights both theoretically and practically. Furthermore, in order to increase international insight, the PKU MUI participants deliberately presented three foreign sources, namely: Prof. Dr. Murood Mahmud Haidar, a professor at Al Azhar University Cairo, Egypt and two resource persons from business practitioners from Muslim Americans, namely Mr. Pedro DeVries and Mr. Huge [16].

\section{3. Learning System}

In implementing the learning process the Semester Credit Unit (SKS) system is used. SKS is an education administration system in which the entire study load of students, teaching staff workload and education provider load are calculated in a unit called credit and implemented in the smallest unit called semester. SKS is a unit used to express the amount of student study load per semester and the amount of recognition of student learning success per semester and the amount of recognition for the cumulative effort of program administrators. While the semester is the smallest unit of time to state the length of a program implemented, equivalent to 12 working weeks, each course presented in each semester is determined by the price of credits which state the weight of the course, the price of 1 credit is equal to 50 minutes of theoretical lecture (face to face with Lecturers / Instructors), 60 minutes of structured study and 60 minutes of independent study.

Activities are carried out face-to-face with lecturers with scheduled lecture activities, where lecturers and students communicate directly with each other in the form of lectures, questions and answers, discussions, seminars and others. Structured learning activities are learning activities outside of scheduled class hours, where students carry out homework assignments, write reports, write papers, research or similar activities. Independent learning activities are learning activities that are organized by students to deepen their knowledge and skills in order to support face-to-face activities with lecturers and structured learning.

\section{4. PKU Institutional Management}

Education of the Ulama Cadre of the Indonesian Ulema Council, Kab. Bogor in its coaching implementation activities has several routine activities, including: PKU Director Has full responsibility to the General Chairperson of the Bogor Regency MUI for the implementation of 
the PKU program where the duties are: Organizing PKU, Organizing academic activities, Organizing administrative activities, Organizing student activities, Making PKU annual work plan, Make routine PKU activity reports to be submitted to the General Chairperson of the MUI Kab. Bogor.

To support the implementation of PKU properly, the manager carries out Quality Control (QC) Management which will be responsible to the PKU director whose main task is to supervise and monitor the implementation of PKU quality management. Among the duties are: Supervising the lecture process, Monitoring the development of PKU participants during lectures, Monitoring the PKU managerial process, Making the main reference for keeping the PKU system running well, Evaluating the PKU process from week to week to determine new supporting policies.

In addition, there is a Ulama Cadre Education Coordinator who is directly responsible to the PKU director and QC Management. Among the tasks, are: Managing the PKU lecture process and activities from the technical side of implementation, Managing the PKU management system together with each field under it, Proposing management or academic improvements to QC Management to be proposed to the PKU Director, Directing the performance of the academic, administrative and academic fields. students in each week of lecture and report it to QC Management.

Furthermore, Academic Affairs, Responsible directly to the PKU coordinator with job descriptions, as follows: Compiling the lecture syllabus and teaching lecturers, Evaluating lecture activities whether they are in accordance with the goals set by the syllabus, Contacting the lecturer and determining a replacement lecturer if the relevant lecturer is unable to attend . Administration Sector, Responsible directly to the PKU coordinator with the following job descriptions: a) Preparing facilities and infrastructure, b) Preparing accommodation and consumption, c) Preparing graduation certificates / diplomas for PKU participants and mementos for agencies related to the PKU program. Student Affairs, Responsible directly to the PKU coordinator with the following job descriptions: a) Recording the PKU lecturers' curriculum vitae, b) Checking the attendance of participants in each lecture, c) Checking the results of learning evaluations from PKU participants for graduation materials from the participants themselves., e) Monitor the attendance of lecturers in collaboration with the academic field.

\section{5. PKU Curriculum}

The PKU program will be adjusted to the development of science and technology, seeing that the function and role of ulama in these days is getting heavier and requires the involvement of many parties to facilitate it. According to KH Mukri Aji, MA as the General Chairperson of the Bogor Regency MUI, the emphasis on the education curriculum for ulama cadres in Bogor Regency emphasizes Islamic-Indonesian issues, judiciary and boredom. These materials are taught so that the program is not only about theories, but also applicable material that can be applied in society, as well as these materials so that they are grounded and not ahistorical, emphasizing local wisdom. It is important to emphasize local wisdom so that the teachings conveyed do not occur counterproductively in the community,

Islamic Studies, namely related to materials specifically studying and studying Islam; related to the science of fiqh, Ushul Fiqh, Tafsir science tafsir, Aqidah and Sufism. Meanwhile, related to Indonesianness, Kejawabaratan and Kebogoran, namely materials related to values or rules related to the Indonesian environment, concerning honesty and boredom. KH Mukri views that the Islamic sciences taught must take into account the local traditions in which they are taught. Because in the rules of ushul fiqh it states "al-'adatu muhakkamatun" local kifan is an important 
consideration in deciding legal cases. We want the ulam cadres to master the local conditions in which they struggle, given that there are several groups that do not respect local traditions, said KH Mukri Aji [17].

Some of the subjects that are considered as Christianity courses include: contemporary inheritance science, contemporary Da'wah Science, Islamic cultivation, Islamic Wordview, Da'wah strategy, Map of the Islamic Network Abroad, Tsamilah maktabah. In addition, core knowledge is still taught such as: Tafsir and science of tafseer, Hadith, hadith, Fiqh and Ushul Fiqh, Comparison of Schools, Arabic and Balghah. To foster an entrepreneurial spirit and independence, the cadres are given entrepreneurial skills that are directly handled by Muslim entrepreneurs who are successful in entrepreneurship. In addition to theoretical materials, PKU is required to participate in field activities aimed at obtaining a concrete and real picture that occurs in the field. One of the series of field activities was a seminar road show with the theme "Preventive Movement to Prevent deviant flow" in five areas in Bogor district, lecturing on Summa radio, internships at several Islamic institutions, and field research.

To increase international and global insight, MUI also presented three speakers from abroad, namely Prof. Dr. Murood mahmud Haidar, professor of Cairo University, Egypt, and two business practitioners from Muslim Americans, namely Mr. Pedro Devries and Mr. Huge. The community's expectation for PKU is that the ulama cadres who are also sons of the region are able to provide offerings as well as the best solution to current public problems in Bogor district.

Tabel 2 :

Books that become references in PKU teaching

\begin{tabular}{cll}
\hline No. & \multicolumn{1}{c}{ Courses } & \multicolumn{1}{c}{ References } \\
\hline 1 & Muqaranah Al-Madzahib & Bidayah Al-Mujtahid; Ibn Rusyd \\
\hline 2 & Qawa'id Al-Fiqhiyyah & Al-Asybah Wa Al-Nazha'ir; Jalaluddin Al-Sayuthi \\
\hline 3 & Ushul Al-Fiqh & Ilm Ushul Al-Fiqh; 'Abd Al-Wahab Khallaf \\
\cline { 3 - 3 } & & Al-Mustashfa: Al-Ghazali \\
\hline 4 & Tafsir Tematik/Mawdhu'i & Tafsir Ayat Al-Ahkam; Al-Shabuni \\
\cline { 3 - 3 } & & Tafsir Al-Munir; Wahbah Al-Zuhayli \\
\hline 5 & Ilmu Tasawuf & Al-Hikam; Ibn 'Atha'illah Al-Sukandari \\
\hline 6 & Qira'at Al-Kutub & Al-Fiyah; Ibn Malik \\
\hline 7 & Ilmu Waris Kontemporer & Rahbiyyah; Sibth Al-Maridani \\
\hline 8 & Hadits Dan Ulum Al-Hadits & Manhaj Dzawi Al-Nazhar; Jalaluddin Al-Sayuthi \\
\cline { 3 - 3 } & & Shahih Al-Bukhari; Al-Bukhari \\
\cline { 3 - 3 } 9 & Al-Fiqh Wa-Al-Qanun & Tarikh Tasyri' Al-Islami; Manna' Al-Qatthan \\
\hline 10 & Masa'il Al-Fiqhiyyah & Fath Al-Mu'in; Zaynuddin Al-Malibari \\
\hline 11 & Aliran-Aliran Modern Dalam Islam & Al-Farq Bayna Al-Firaq; Abu Manshur Al-Asfirayini \\
\hline
\end{tabular}

In addition to PKU participants getting the courses above, in learning they also use books, modules and textbooks that are enrichment in nature.

\section{6. Assessment and Evaluation}


This evaluation was carried out to test how far the PKU participant's ability to absorb the knowledge he got during the learning process at PKU. The certificates that will be given are the official certificates given from the MUI of Bogor Regency and the Regional Government of Bogor Regency.

Every month, a monthly exam is conducted to determine the participant's mastery of the material that has been presented and as a provision for more intensive coaching. At the end of the program a general exam is held covering all subjects. Participants who have passed will be given a certificate.

Course Examination Evaluation, consisting of: Course Examination (UMK) is carried out by the relevant lecturer at the last meeting, and the Final Education Examination (UAP) is held at the end of the lecture. Apart from UK and UA, lecturers can also give direct assignments or exams in the form of oral examinations or observation assignments. The level of mastery of student material is measured by a measurement instrument whose results are expressed as a score.

Achievement Index (IP) is a number that states the level of success of a student, both quality and quantity, the IP is calculated at the end of each month. Meanwhile, the Grade Point Average (GPA) is calculated at the end of the education program. Students who pass the final (comprehensive) exam will be awarded a diploma by the Bogor Regency Indonesian Ulema Council, then a graduation ceremony will be held which will present important figures and officials.

\section{7. Activity Financing}

All funding during the PKU MUI activity program receives grant funds from the Bogor Regency Regional Government. This grant is provided by the local government to MUI in Bogor Regency for all MUI activities, therefore the PKU program funding is part of the grant funds for MUI activities.

For eight generations, from 2006 until now the local government has provided a grant of 2 (two) billion every year. The funds are used for activities in carrying out MUI programs. The local government provides these funds, one of which is MUI as a government partner who has provided guidance to the people of Bogor Regency, of course in line with the vision and mission of the local government, namely realizing social piety [18].

\section{PKU Program Continuity}

The sustainability of a program is determined by many aspects. Likewise, the Bogor district PKU program will run effectively as expected if it is carried out carefully, especially for the sustainability of the program and after participants have finished participating in the PKU program. Some of the factors that influence the sustainability of the PKU program in Bogor Regency are: 1) Leadership of the MUI Chair, 2) Young people as PKU drivers, and 3) Supporting Financing.

Leadership is one of the determinants of program success. This is where the role of the leader who designs and coordinates the implementation of the program. The PKU program in Bogor from time immemorial has always been the concern of ulama and MUI administrators, even routine moments such as the MUI deliberations have always been a debate that is quite time and energy consuming. under the leadership of Dr. KH Mukri Aji, MA, the PKU program at MUI Bogor began to materialize, namely since 2006.

KH Mukri Aji once participated in the PKU Central MUI Batch I representing the DKI Jakarta Province (1990). This experience underlies the birth of PKU in Bogor Regency. He 
shared his ideas and experiences during the PKU program. As a preacher, cleric and once a politician, KH Mukri has a wide network among pesantren, ulama, scholars, religious organizations, Muslim businessmen, political figures and local governments. At least the network they have is the capital to develop the ulama cadre program. He is able to embrace and foster the younger generation to actively raise PKU. He has also been a Lecturer at PKU DKI Jakarta (1994-1997), Postgraduate Lecturer at Univ. Ibnu Khaldhun (2001 - skr), Member of the DPRD Commission D (Development Sector) Kab. Bogor (1997-1999).

In management, PKU MUI Bogor Regency involves a lot of young generations / people, especially after the first PKU activities involving PKU alumni became the support for the activity. For Irvan Zaryab (PKU Alumni coordinator) and friends to feel comfortable and connected with the leadership of KH Mukri Aji as Chairman of the MUI, he always fosters and provides support for the ideas conveyed to us as the younger generation. Likewise, Pak Kyai's ideas and ideas are supported by young people [19].

The elders become the protector and encouragement for young people, and young people do not hesitate to ask for advice and guidance from the elders. An atmosphere of mutual support between the elderly and young is communicative towards the implementation of MUI programs, especially Ulama Cadre Education, almost all MUI activities that become the activator and implementer are young people.

KH Mukri's experience when he became a Central First PKU participant and head of the district ulama cadre education. Bogor, at every meeting and deliberation there are always ideas to pass PKU activities, but these programs and ideas run aground in the middle of the road and have not been implemented, only after KH Mukri became Chairman of the MUI district. Bogor began to be done by involving all stakeholders in the MUI (Islamic mass organizations) and the younger generation. This is what distinguishes the PKU MUI Bogor program from other PKU programs, young people become the movers of the PKU program. Among the youths: Irvan, Fuad Hasan, Tohiruddin Rahmat, Romli (secretary of the MUI), Ujang Ruhiyat, etc.

Since the leadership of Regent Rahmat Yasin when he was chairman of the DPRD and after becoming the Regent, MUI activities in Bogor Regency have always received activity grants amounting to 2 billion annually. This grant fund is one of the pillars of the MUI program activities at both the district and sub-district levels. Including funds for the activities of the MUI ulama cadre education program (PKU) in Bogor district. This allocation of funds also received support from council members, even all factions approved the allocation of grant funds to develop communities in the district [20].

MUI Bogor has good closeness to the local government, because of that closeness to the district government. Bogor includes elements of the MUI into the ranks of the Muspida in determining local government policies. Synergy of Ulama and Umara is the Key to the Success of Bogor Development, for the Head of MUI Kab. Bogor KH Mukri Aji: The success of the Bogor MUI cannot be separated from the role of the Bogor district government. "Good and intense communication between the local government and the ulama facilitates the development process of Bogor district to be more informed, because the Bogor regional government is able to balance physical and non-physical development (in the form of religious and cultural awareness) [21].

Synergy of Ulama and Umara is the Key to the Success of Bogor Development, for the Head of MUI Kab. Bogor KH Mukri Aji: The success of the Bogor MUI cannot be separated from the role of the Bogor district government. "Good communication and instinct between the regional government and the ulama facilitates the development process of Bogor district to be more informed, because the Bogor regional government is able to balance physical and non-physical development (in the form of religious and cultural awareness) [22]. 


\section{Closing}

The practice of organizing ulama cadre education (PKU) at MUI in Bogor Regency is one of the successful educational alternatives for ulama cadres, because it is supported by internal and external factors. Internal aspects of the MUI due to the personal leadership of the Bogor Regency MUI (KH Mukri Aji), the support of the younger generation, PKU alumni. Meanwhile on the external aspect due to the synergy factor of ulama and umara, namely the support of PKU program funding from the local government, networks with religious institutions (Islamic organizations) and universities.

The management of ulama cadre education at MUI Bogor Regency is influenced by leadership in carrying out the functions of planning, organizing, implementing and evaluating programs. In carrying out its functions, the MUI leadership has mobilized the role of the younger generation in utilizing human resources (HR, especially PKU alumni, in direct management, synergizing programs with local governments so that they can provide program funding, open networks with various components of society.

Although the Ulama Cadre Education in Bogor Regency is carried out regularly every year by getting activity funds from the local government, the continuity of the implementation of this program will cause problems or obstacles if program funding still relies on the local government.

Some suggestions in this study are: 1) PKU program as an alternative education program to develop human resources in the community of Bogor Regency. 2) The need for continuous PKU alumni coaching, through a care program for local leaders, MUI administrators, so that the potential that alumni have during their education can be utilized and implemented in the community. 3) In order for the PKU program to continue, the Bogor Regency MUI needs to make a productive program in terms of funding, if the government does not support PKU activities or in financial conditions that are not possible, for example through maximizing the waqf program or productive zakat.

\section{Thank You Note}

The author conveys the greeting Thank you to the Head of the Research and Development Center for religious and religious education who has funded this research and for this international seminar in collaboration with the Indonesian Religious Researchers Association (APAI) located in Jakarta, Indonesia. Hopefully this article will be useful for religious education institutions and the academic world.

[1] Book: Author AA. Title of book. Edition [if not first]. Place of publication: Publisher; Year of publication. Pagination.

\section{References}

[1] HM Muhtarom. Reproduksi Ulama di Era Globalisasi: Resistensi Tradisional Islam. Yogyakarta: Penerbit Pustaka Pelajar, (2005).

[2] Laporan Penelitian. Evaluasi Program Pendidikan Ma'had Aly. Jakarta: Puslitbang Pendidikan Agama dan Keagamaan, Jakarta. (2003). 
[3] Laporan Penelitian. Persepsi dan Aspirasi Masyarakat tentang Penyiapan Ulama di Pesantren. Jakarta: Puslitbang Pendidikan Agama dan Keagamaan. (2007).

[4] Laporan Penelitian. Needs Assessment Pengembangan Kurikulum Ma'had Aly. Jakarta: Puslitbang Pendidikan Agama dan Keagamaan. (2008).

[5] HM Muhtarom. Reproduksi Ulama di Era Globalisasi: Resistensi Tradisional Islam. Yogyakarta: Penerbit Pustaka Pelajar. (2005).

[6] Kementerian Pendidikan dan Kebudayaan. Kamus Besar Bahasa Indensia. Jakarta : Penerbit Balai Pustaka. p. 1059.

[7] M. Quraish Shihab. Membumikan Al-Qur'an: Fungsi dan Peran Wahyu dalam Kehidupan Masyarakat . Bandung : Penerbit Mizan. (1992).p. 385.

[8] Azyumardi Azra. Ulama, Politik dan Modernisme. Jurnal Ulumul Qur'an Vol.II. 1990/1411 H, p..5-6

[9] Riset Redaksi Gong: Jurnal Studi Islam dan Budaya, No 07/TH V/1996, "Membongkar Mitos-Mitos Ulama", p. 3

[10] Azyumardi Azra. Pendidikan Islam: Tradisi dan Modernisasi Menuju Milenium Baru. Jakarta : Logos Wacana Ilmu. (2002). p. 145

[11] Azyumardi Azra. Pendidikan Islam: Tradisi dan Modernisasi Menuju Milenium Baru. Jakarta : Logos Wacana Ilmu. (2002). p. 104

[12] Aji, Mukri. 2014. Interview of "Pendidikan Kader Ulama di Kabupaten Bogor" on his Office, J1. Tegar Beriman 1.

[13] Aji, Mukri. 2014. Interview of "Pendidikan Kader Ulama di Kabupaten Bogor" on his Office, J1. Tegar Beriman 1 Bogor.

[14] Aji, Mukri. 2014. Interview of "Pendidikan Kader Ulama di Kabupaten Bogor" on his Office, Jl. Tegar Beriman 1 Bogor.

[15] Zaryab, Irfan. 2014. Interview of "Pendidikan Kader Ulama di Kabupaten Bogor" on his Office, J1. Tegar Beriman 1 Bogor

[16] Zaryab, Irfan. 2014. Interview of "Pendidikan Kader Ulama di Kabupaten Bogor” on his Office, J1. Tegar Beriman 1 Bogor

[17] Aji, Mukri. 2014. Interview of "Pendidikan Kader Ulama di Kabupaten Bogor" on his Office, J1. Tegar Beriman 1 Bogor

[18] Setiawan, Dodi. 2014. Interview of "Pendidikan Kader Ulama di Kabupaten Bogor" on his Office, J1. Tegar Beriman 1 Bogor.

[19] Zaryab, Irfan. 2014. Interview of "Pendidikan Kader Ulama di Kabupaten Bogor" on his Office, J1. Tegar Beriman 1 Bogor.

[20] Romli, Muhammad. 2014. Interview of "Pendidikan Kader Ulama di Kabupaten Bogor" on his Office, Jl. Tegar Beriman 1 Bogor

[21] Kalam Ulama, Majalah MUI Kab. Bogor, Edisi 5/Tahun III/Desember 2013/Rabiul Awal 1435, p. 32.

[22] Kalam Ulama, Majalah MUI Kab. Bogor, Edisi 5/Tahun III/Desember 2013/Rabiul Awal 1435, p. 34 